\title{
The Incidence of Orofacial Cleft in Wassit
}

\author{
Abdulkhudhur A alwan \\ Lecturer Dr. B.D.S-F.C.A.B.M.S. Maxillofacial Surgeon/Wassit University-Iraq
}

\begin{abstract}
Cleft lip and palate are the second most common congenital deformity after club foot. The aim of this study is to determine the incidence of orofacial cleft in Wassit.This a retrospective study is diagnosed 300 patients with various types of orofacial cleft from 125800 live births. The incidence of clefts in our population higher than other countries. Cleft lip and palate are more common than other types of orofacial cleft and more common in male than female. While isolated cleft palate are more common in female than male.
\end{abstract}

Keywords: Incidence, orofacial cleft.

\section{Introduction}

Cleft lip and palate are the second most common (about 1 in 700 live births) congenital deformity, after club foot deformity, these localized clefts produce multiple local and regional medical challenges: they affect face shape, speech, and swallowing, as well as increase the frequency of middle ear infections. ${ }^{(1)}$

Isolated cleft palate (CP) occurs with a genetic pattern differ from that of cleft lip (with or without cleft palate)." The cleft lip incidence is $0.47 \%$ of live births, with a male: female ratio of 0.74 (in Caucasians) (2) while the occurrence of cleft lip with palate varies among genetic groups, 0.4 per 1000 in blacks, 1 per 1000 in Caucasians, 1.5 per 1000 in Chines, 2.2 per 1000 in Japanes, and 3.5 per 1000 in Amerindians (3). The M:F ratio of CL/P is $2: 1$ and of CL is $1.55: 1$ (in Caucasians)'”(2).

Aim of Study: Determine the incidence of orofacial cleft in Wassit and provide database for health care foundation to improve the provided care.

\section{Patients and Method}

This a retrospective study is include all the live birth in was sit between May 2013-May 2018. All the variants of orofacial clefts were recorded in this study. All the normal and abnormal perineonatal deaths were excluded from this study. The number of orofacial clefts in this study depends on the documentation of oral and maxillofacial department which the only center in the government deals with such cases, due to poor registration of hospitals regarding the congenital deformities.

\section{Result}

For five years, all the hospital in wassit recorded about 125800 live birth. Three hundred patients with orofacial cleft attended to department of oral and maxillofacial surgery which the only department that receive such cases in the wassit government, 2.3 for 1000 birth.

From 125800 live birth, 170 patients were presented with cleft lip and palate (1.3 for 1000 birth). while 25 patients with isolated cleft palate $(0,01$ for 1000 birth), and 105 with cleft lip only( 0.8 for 1000 birth),table 1 .

From 300 cases with orofacial cleft,105 are cleft lip, 170 are cleft lip and palate and 25 cases present with isolated cleft palate, table 2 .

From 170 patients were presented with cleft lip and palate 110 patients were male(64\%) and 60 were female (35\%),from 105 patients with cleft lip, 75 were male and 30 were female,from 25 patients with isolated cleft palate, 20 were female $(80 \%)$ and 5 were male $(20 \%)$, table 3 .

Table (1) Incidence of orofacial cleft

\begin{tabular}{|l|c|c|}
\hline Cleft Type & No. of Cases & Incidence (per 1000) \\
\hline Cleft lip & 105 & 0.83 \\
\hline Cleft lip \& palate & 170 & 1.35 \\
\hline Cleft palate & 25 & 0,2 \\
\hline All types of cleft & 300 & 2.38 \\
\hline
\end{tabular}


Table (2) Percentage of orofacial cleft

\begin{tabular}{|l|c|c|}
\hline Cleft type & No. of cases & Percentage (300 cases) \\
\hline Cleft lip & 105 & $35 \%$ \\
\hline Cleft lip \& palate & 170 & $56 \%$ \\
\hline Cleft palate & 25 & $9 \%$ \\
\hline
\end{tabular}

Table (3) Sex distribution of orofacial cleft

\begin{tabular}{|l|c|c|}
\hline \multirow{2}{*}{ Cleft type } & \multicolumn{2}{|c|}{ Sex } \\
\cline { 2 - 3 } & Male & Female \\
\hline Cleft lip & 75 & 30 \\
\hline Cleft lip \& palate & 110 & 60 \\
\hline Cleft palate & 5 & 20 \\
\hline Total & 190 & 110 \\
\hline
\end{tabular}

\section{Discussion}

In this study the incidence of orofacial cleft in our government slightly higher than other countries that may be explain by: the relative causes of clefts are the following :genetic,environmental, and developmental factors. The occurrence of orofacial cleft in families containing varied numbers of clefts conclude that the interaction of three to six genes that responsible for this malformation ${ }^{(4)}$.MSX1 and TGF b3 are among the most responsible genes (3). There are over 350 known syndromes associated with clefts of which half are of monogenic origin (5),in our population many of parents are genetically related,especially in the rural area,also that explain why the prevalence higher in rural area(periphery) than the center of city (urban), when the parents belong to one grant family(second or third relative) when the genetic factor play a great role in this situation. Also higher incidence of orofacial cleft in our population may be belong to environmental cause: when high percentage of pregnant ladies suffering from anemia, uterine viral infection and malnutrition (vitamin deficiency) ${ }^{6}$, and deficient of regular follow up during pregnancy to avoid the the environmental precipitating factor like: folic acid, vitamin B6, B12 and iron deficiencies.

In this study cleft lip and palate higher than cleft lip or cleft palate only,and this is agree with most of studies.

Also in this study the incidence of cleft lip and cleft lip and palate higher in male than female in contrast to isolated cleft palate higher in female than male and it is agree with most of studies.

\section{Conclusion}

1. The incidence is higher in our government than other developed countries.

2. The incidence is higher in low socioeconomic people.

3. Cleft lip and palate higher than other types of clefts.

4. Isolated cleft palate higher in female than male.

\section{Suggestions:}

1. The health care providers in the government should be improved their efforts to get expansion in number of orofacial cleft and establish large qualified center.

2. Regular gynecological follow-up to the pregnant ladies to avoid environmental causes anemia, vitamin deficiencies, viral infection etc.

3. Regular visits to rural area to avoid late diagnosis, as the surgical intervention should be in fixed schedule.

4. Provide good and continuous training for health provider and work as multidisciplinary team.

Ethical Clearance: The Research Ethical Committee at scientific research by ethical approval of both $\mathrm{MOH}$ and MOHSER in Iraq.

\section{Conflict of Interest: Non}

Funding: Self-funding

\section{References}

1. Rogers BO. Harelip repair in colonial America. In: McDowell F, ed. The Source Book of Plastic Surgery. Baltimore, MD: Williams \& Wilkins, 1977:180-200.

2. Tolorova MM. Classification and birth prevalence of orofacial clefts. Am J Med Genet 1998; 75:126.

3. Gorlin RJ, Cohen MM, HennekamRCM. Orofacialcleftingsyndromes: general aspects. Syndromes of the Head and Neck. Oxford: Oxford University Press, 2001:850-76.

4. Schliekelman P, Slatkin M. Multiplex relative risk and estimation of the number of loci underlying an inherited disease. Am J Hum Genet 2002; 71(6):1369-85.

5. Marazita ML, Mooney MP. Current concepts in the embryology and genetics of cleft lip and cleft palate. Clin Plast Surg 2004; 31:125.

6. Sadove AM, van Aalst JA, Culp JA. Cleft palate repair: art and issues. Clin Plast Surg 2004; 31:231. 